He has written no text-books and has given the science little theory as compared with the great amount of research work he has done. When asked for theory he answered with experiment. Theories change but the experimental work found on the pages of these volumes will stand the test of time.

G. B. FrankForter.

A Laboratory Handbook for the ANalysis of Milk, Butter aNd Cheese. By James Rittengouse Evans, B.S. $1905.60 \mathrm{pp}$., $2 \mathrm{~d}$ ed. Price, \$r.40.

The chief merit of the book is its form of presenting methods in distinct steps, an arrangement that is of advantage for one using the methods for the first time. The methods could in many cases have been given with greater fulness to advantage. The method given for estimating casein and albumin is quite out of date. A serious omission is the failure to describe the use of the Quevenne lactometer in determining solids and solids-not-fat in milk. It is doubtful if one could detect skim-milk or watered milk satisfactorily by following the meagre directions given.

L. I. VAN Slyke.

AMERIKANISCHES HochschULWESEN: EINDRÜCKE UND BETRAChTUNGEN. von DR. W. BöTTGER, Privatdozent an der Universität Leipzig. Leipzig: Wilhelm Engelmann. Igo6.

The author of this little brochure spent a year in research work at the Massachusetts Institute of Technology and his impressions of the contrast between American and German universities are based upon careful observation and are extremely interesting and instructive. Their value is increased, especially for German readers, by means of a number of careful, detailed illustrations of the character of the work in American institutions.

W. A. N.

\title{
RECENT PUBLICATIONS.
}

The Laboratory Book of Mineral Oil-testing. By J. A. Hicks. London: 1906. $88 \mathrm{pp.} 2 / 6$.

Guide Pratiquf DE L'EXPERT-Chimiste EN DENREAS Alimentaires. By D. Pellerin. Paris: Berger-Levrault. 1906. $8+682$ pp. I I francs.

CHEMIE UND CheMische WARENKUNDE F. ZOLlbeaMte. UNTER BerǘckSICHT DER ERLÄUTERGN. ZUM ZOLLTARIF F. DAS OSTER-UNGAR. ZOLIGEBIET vom 13. By Franz Freyer. Wien: Firck. 1907. $8+562$ pp. 6 marks. 